\title{
Advancement in the Utilization of Biomass-Derived Heterogeneous Catalysts in Biodiesel Production
}

\section{Nurudeen Ishola Mohammed ${ }^{1}$, Nassereldeen Ahmed Kabbashi ${ }^{1}$, Abass Olanrewaju Alade ${ }^{2}$, Sarina Sulaiman 1}

${ }^{1}$ Bioenvironmental Engineering Research Centre (BERC), Department of Biotechnology Engineering, Faculty of Engineering, International Islamic University Malaysia, Kuala Lumpur, Malaysia

${ }^{2}$ Chemical Engineering Department, Faculty of Engineering, Ladoke Akintola University of Technology, Ogbomoso, Nigeria

Email: *sholanourou@yahoo.com, somao4all@gmail.com

How to cite this paper: Mohammed, N.I., Kabbashi, N.A., Alade, A.O. and Sulaiman, S. (2018) Advancement in the Utilization of Biomass-Derived Heterogeneous Catalysts in Biodiesel Production. Green and Sustainable Chemistry, 8, 74-91.

https://doi.org/10.4236/gsc.2018.81006

Received: November 3, 2017

Accepted: February 5, 2018

Published: February 8, 2018

Copyright $\odot 2018$ by authors and Scientific Research Publishing Inc. This work is licensed under the Creative Commons Attribution International License (CC BY 4.0).

http://creativecommons.org/licenses/by/4.0/

c. (i) Open Access

\begin{abstract}
Solid oxide catalysts derived from various renewable sources have produced significant yield of methyl esters of enhanced purity. These materials are sourced for due to their advantages ranging from low cost, recoverability and reusability, environmental benign-ness, thermal stability and high quality product generation. For a possible greener production process, many researchers in literature reported the use of biomass-derived heterogeneous catalyst in biodiesel synthesis producing high quality pure product. The catalysts were majorly modified through simple physical cost effective and energy saving operations. This paper explores some of these bio-based heterogeneous catalyst used in biodiesel production via transesterification and esterification approach and their performance in FAME yield and conversion. The feedstock consideration which warrant the route selection, various approaches that are adopted in biodiesel production, performance of renewable heterogeneous catalyst and the measures that were adopted to enhance efficiency of the catalyst were considerably highlighted. It is observed that the prospects of organic-based solid catalyst in biodiesel development is a promising enterprise compared to the conventional methods utilizing homogeneous chemical catalyst, which generates wastewater requiring treatment before disposal and generates product that may cause engine malfunction. This review work aimed at providing detailed and up-to-date record of the trend in renewable catalyst development in biodiesel synthesis. This is expected to inform a suitable selection and reaction conditions in the development of biodiesel from the very many feed stocks.
\end{abstract}




\section{Keywords}

Biodiesel, Feed Stocks, Catalysis, Catalyst Performance, Biomass-Derived Catalysts

\section{Introduction}

Increasing energy demand and the crisis of global warming as a result of fossil fuel consumption among others are the exigencies for development of bio-based fuel such as biogas and biodiesel. Biodiesel has recently received kindled attention due to its various advantages and it proffering solutions to some of the environmental problems identified with fossil fuel consumption. It provides an alternative energy safety compared to petroleum based fuel; it is a renewable and non-toxic fuel, allows a favorable energy augmentation, and has considerably fewer in pollutants emissions when compared to fossil fuels.

The term biodiesel has been used to describe diesel-equivalent fuel produced from renewable biological sources. In chemical term, it is known as monoalkyl ester of long chain fatty acids that is produced from bio-lipids. It is synthesized by the reaction involving short chain monohydric alcohols such as methanol, ethanol, propanol and butanol and vegetable oils or animal fats usually in the presence of a catalyst to produce alkyl esters (biodiesel) and glycerine [1].

Conventional biodiesel production is a transesterification reaction of triglycerides of vegetable oils or fats with alcohols like methanol and ethanol in the presence of a homogenous base catalyst such as $\mathrm{NaOH}$ or $\mathrm{KOH}$ to yield fatty acid alkyl esters (i.e., biodiesel) and glycerol [1]. Sustainably, predominant biodiesel feedstocks around the world utilize low cost materials and the cost of the biodiesel fuels depend on the price of the feedstock. These cheap resources include palm oil in Asian country like Thailand, Indonesia and Malaysia. While India and Brazil utilizes Jatropha curcas oil as the raw material by a transesterification reaction method using alkali catalysis. Other regions such as Europe use low grade waste cooking oil as cheap resource [2] [3].

Apart from the feedstock, catalyst and the alcohol used are the other contributing factor to the cost of the product. Short chain alcohol usually methanol and ethanol are majorly considered due to the low cost of methanol and the renewable nature of ethanol. Biodiesel produced from methanol performs better compared to ethanol-synthesized biodiesel. The use of ethanol supports sustainable development because it is renewable. However, the use of ethanol is problematic due to easy formation of emulsions; thereby the separation of the end product is more difficult. This is more prevalent with feedstocks of high FFA content such as waste cooking oil [4].

Catalysis in biodiesel development plays an important role in rate of product generation. Selection of catalyst for biomass conversion is primarily dependent on the amount of free fatty acids in the oil. Purity of the synthesized biodiesel 
fuel utilizing homogeneous catalyst practically cannot be guaranteed as it is not economically feasible to completely recover the catalyst from the product. This affect the performance of the fuel when use in diesel engine. Biodiesel production has been reported via catalyzed and non-catalyzed processes. Non-catalyzed process includes supercritical alcohol process. Furthermore, the use of pure biodiesel in diesel engines is capable of zero carbon dioxide emission [5] [6] [7]. Biodiesel blends are used in diesel engine to reduce $\mathrm{CO}_{2}$ emission, to discourage accumulation of shoot and prevent engine malfunction which is common with usage of pure biodiesel.

\section{Biodiesel Feedstocks}

Majority of biomass have been investigated by many researchers throughout the world. The production of biodiesel from oil origin has utilized feedstocks in different locations due to their relative abundance and oil content. For instance, in USA, the combined vegetable oil and animal fat production amounts to about 35.3 billion pounds per year [8]. Similarly, in Brazil, since the advent of the first biodiesel plant in 2005, Brazilian production has witnessed prime increase with about 2 million tons/year in 2009 exploring about 60 plant oils [9]

Moreover, as at 2002, of the world production of biodiesel, about $84 \%$ was from rapeseed oil, $13 \%$ from sunflower while palm oil and soybean biodiesel both recorded 1\% [10], subject to the availability of these seed oil and the energy needs in the various locations of the world. Commercially, majority of biodiesel currently synthesized utilizes soybean oil in Brazil, rapeseed oil in Europe and United States, palm oil is the major biodiesel feedstock in Malaysia and Indonesia with methanol, and an alkaline catalyst. The high value of soybean oil as food product makes production of a cost effective fuel very challenging [2] [3].

Myriad of other sources of biodiesel feedstock have been investigated, these include almond, andiroba (Carapa guianensis), babassu (Orbignia sp.), barley, camelina (Camelina sativa), coconut, copra, cumaru (Dipteryx odorata), Cynara cardunculus, fish oil, shear butter oil, groundnut, Jatropha curcas, karanja (Pongamia glabra), laurel, Lesquerella fendleri, Madhuca indica, microalgae (Chlorella vulgaris), oat, piqui (Caryocar sp.), poppy seed, rice, rubber seed, sesame, sorghum, tobacco seed, and wheat [11]. These vegetable oils are renewable fuels which have recently been considered more attractive due to their environmental benefits and renewability. World vegetable oil production rose from 56 million tons by $60 \%$ in one decade, following a below-normal increase. The source of this gain was distributed among the various oils. Global consumption increased from 56 million tons to 86 million tons, leaving world stocks comparatively competitive [1].

A variety of bio-lipids are employed in the synthesis of biodiesel. These are 1) virgin vegetable oil feedstock; rapeseed and soybean oils are the most commonly used, though other crops such as mustard, palm oil, sunflower, hemp, and even algae oil had been investigated;2) waste vegetable oil;3) animal fats including 
tallow, lard, and yellow grease; and 4) non-edible oils such as Jatropha curcas, neem oil, castor oil, tall oil, etc., are other feedstock resources from which the fuel had been produced. The widespread use of soybeans in the USA for food products has led to the emergence of soybean oil as the primary source for biodiesel in that region [1].

In recent time, rekindled attention had been accorded to vegetable oils due to their environmental advantages and their organic root [9] [12]. Vegetable oils possess huge potential to be use in place of a significant proportion of petroleum distillates and fossil chemicals in the near future. Current market price of vegetable-oil does not allow a remarkable rivalry with petroleum-based fuels because they are more expensive. Nevertheless, the recent inflation in price of crude oil and uncertainty surrounding petroleum availability caused the intensified $\mathrm{cu}-$ riosity and consideration for vegetable oils based diesel fuel.

Of the more than 350 oil-bearing crops that have been identified, only soybean, palm, sunflower, safflower, cottonseed, rapeseed, and peanut oils are considered potential alternative fuels for diesel engines [13] [14]. Table 1 shows the oil species that can be used in biodiesel production.

Global utilization of soybean oil reached the ultimate in 2003 amounting to about 27.9 million metric tons [1]. Renewability of Vegetable oils is certain and unlike petroleum based fuel, it cannot be depleted, providing an energy equivalent comparable to diesel fuel. However, exploitative consumption of vegetable oils (especially edible oils) may result in potential problems such as starvation in developing countries unless non-edible oils are sought for as materials in production of energy resources.

In South East Asia, palm oil remains the major oil seed feedstock used as a significant biodiesel source, while sludge from palm oil mill effluent has extensively been investigated as another resource utilized in the development of biodiesel, though low yield have been recorded. In Europe, the most common feedstock for biodiesel synthesis is rapeseed oil. The use of Jatropha curcas oil as

Table 1. Vegetable oil resources for biofuel production.

\begin{tabular}{|c|c|}
\hline Group & Source of oil \\
\hline Predominant oils & $\begin{array}{l}\text { Coconut, copra, cottonseed, canola, olive, peanut, } \\
\text { safflower, sesame, soybean, and sunflower. }\end{array}$ \\
\hline Nut oils & Almond, cashew, hazelnut, macadamia, pecan, pistachio and walnut. \\
\hline Other edible oils & $\begin{array}{l}\text { Amaranth, apricot, argan, artichoke, avocado, babassu, bay laurel, beech nut, } \\
\text { ben, Borneo tallow nut, carob pod, cohune, coriander seed, false flax, grape } \\
\text { seed, hemp, kapok seed, lallemantia, lemon seed, macauba fruit, meadow } \\
\text { foam seed, mustard, okra seed, perilla seed, pequi, sinica seed or Niger pea, } \\
\text { rice bran, tallow, tea thistle, and wheat germ. }\end{array}$ \\
\hline Non-edible oils & $\begin{array}{l}\text { Algae, babassu tree, copaiba, honge, Jatrophaor ratanjyote, } \\
\text { jojoba, karanja or honge,mahua, milk bush, nagchampa, neem, } \\
\text { petroleum nut, rubber seed tree, silk cotton tree, and tall. }\end{array}$ \\
\hline Other oils & Castor, radish, and tung. \\
\hline
\end{tabular}

Source: [1]. 
feedstock is predominant in India and Southeast Asia and some part of Africa. Algae, another oil feedstock can be grown at any location with enough sunshine while some species are capable of growth in salty environment. Of importance is the yield content of algal oil reported to be high, on which biodiesel yield produced from it solely depends [1].

\section{Catalysis in Biodiesel Production}

\subsection{Homogeneous Catalysis}

The most common alkaline catalysts employed in biodiesel development are sodium hydroxide $(\mathrm{NaOH})$ and potassium hydroxide $(\mathrm{KOH})$ [15] [16] [17]. The use of other alkaline catalysts such as Carbonates, Methoxide, Sodium ethoxide, Sodium propoxide and Sodium butoxide have also been investigated [18]. The high yield production of fatty acid alkyl esters under conditions of low temperature and pressure within a short duration make this method economically viable [19] [20].

The main drawback of this approach is the feedstock purity requirement. The presence of free fatty acids, water and some other impurities in the feedstock has a pronounced effect on the process of transesterification [16] [21]. Besides, the complicated multi-step downstream operations of end products is another hindrance. Moreover, the treatment of the generated wastewater from this process incurs additional cost which further impede the economical sustainability of the method. The amount of wastewater produced is approximately 0.2 ton for every ton of biodiesel produced. The need for extensive downstream processing makes alkaline transesterification expensive and a threat to environmental sustainability [22].

The requirement for reaction homogeneity has informed the use of homogeneous base catalyst in biodiesel synthesis. Homogeneous catalysts are very effective and cheap reagents, nevertheless, the limitation of product purification required subsequently for their methyl esters washing escalates the cost. Besides, catalyst reuse is a problem after enormous energy, water, and time have been expended [23].

In practice, $\mathrm{NaOH}$ is preferred over potassium hydroxide because it causes less emulsions and is less expensive. There are various reports of use of $\mathrm{NaOH}$ as a catalyst for biodiesel production [23]. The use of $\mathrm{KOH}$ as base catalyst in the transesterification process has been widely reported also, however, $\mathrm{KOH}$ is reported to offer better fuel performance compared to $\mathrm{NaOH}$ and the separation of glycerol from biodiesel is easier with $\mathrm{KOH}$ when utilized as a catalyst; therefore it is preferred over $\mathrm{NaOH}$ [23] [24].

Sodium methoxide $\left(\mathrm{NaOCH}_{3}\right)$ is more effective than sodium hydroxide as a catalyst because it disintegrates into $\mathrm{CH}_{3} \mathrm{O}_{2}$ and $\mathrm{Na}^{+}$and does not produce water in contrast to $\mathrm{NaOH} / \mathrm{KOH}$. Moreover only $50 \%$ of it is required compared to $\mathrm{NaOH}$. But the catalyst is less common due to its higher cost. It was found that $0.5 \%$ sodium methoxide and $1 \%$ sodium hydroxide exhibited similar results with 
methanol-to-oil molar ratios of 6.44. The use of $\mathrm{NaOCH}_{3}$ is reported more in literature as observed by [25] [26]. Similarly, Potassium methoxide $\left(\mathrm{CH}_{3} \mathrm{OK}\right)$ is a base catalyst which can also be used for transesterification. Although it has been tested by many researchers, very few have recommended using it on regular basis [27] [28] [29].

\subsection{Heterogeneous Catalysis}

The heterogeneous catalysis approach in biodiesel production reduces the difficulties of separation of products and catalyst, resulting in the generation of lower volume of effluent and reusability of the catalyst [30] [31]. Currently, reports in literature suggests the use of various acid and basic heterogeneous catalysts, however, heterogeneous chemical catalysis generally generate low yields compared to homogeneous alkaline catalysts [30] [32].

In contrast, heterogeneous (solid) base catalysts are easily separated simply by filtration and can be reused several times. Commonly employed solid base catalysts include the alkaline earth metal oxides, zeolites, $\mathrm{KNO}_{3}$ loaded on $\mathrm{Al}_{2} \mathrm{O}_{3}$, $\mathrm{BaO}, \mathrm{SrO}, \mathrm{CaO}$ and $\mathrm{MgO}$ [23]. Among the alkaline earth metal oxides $\mathrm{CaO}$ is the most widely used as a catalyst for transesterification producing up to $98 \% \mathrm{FAME}$ yield in the first reaction cycle [33]. The reactivity of $\mathrm{CaO}$ can be improved further by subjecting it to calcination. However, the reusability of the catalyst for further reaction cycle remains in question. Boron and carbon group elements have been extensively investigated. Boron group elements particularly aluminum and $\mathrm{Al}_{2} \mathrm{O}_{3}$ serving as support for various other metal oxides, halides, nitrates and alloys are used for biodiesel production [34] [35] [36].

Besides, transition metals have also been reported with great catalytic effectiveness in biodiesel production. Common among the transition metals and their oxides employed in biodiesel synthesis are $\mathrm{ZnO}, \mathrm{TiO}, \mathrm{TiO}{ }_{2} / \mathrm{SO}_{22}$ and $\mathrm{ZrO} \mathrm{r}_{2} / \mathrm{SO}_{4}$ [23]. Zeolites as catalysts possess the characteristics of acidic sites and shape selectivity. Zeolites vary in pore structure and the inner electric fields from their crystal as well as their surface properties contribute to their varying catalytic properties. Zeolites can accommodate a wide variety of cations such as $\mathrm{Na}^{+}, \mathrm{K}^{+}$, $\mathrm{Ca}^{2+}, \mathrm{Mg}^{2+}$ and many more, which contribute to their basic nature. Zeolites as potential heterogeneous catalysts for the preparation of biodiesel have been investigated in myriad of studies [37].

\subsection{Enzymatic Catalysis}

Lipases (E.C.3.1.1.3) are a class of hydrolase that are known to be responsible for hydrolysis of acyl glycerides. They are produced from microbial plant and animal species. Industrial production levels of these enzymes are from microbial sources. Organisms "Generally Regarded As Safe (GRAS) such as Aspergillus species, Penicillia species and Candida species etc. are the sources from which these enzymes have been produced. Lipase possesses further importance in that they exhibit stability at diverse $\mathrm{pH}$ range, temperature and organic solvent and 
are known to be capable of existing in intracellular and extracellular nature [7].

Biocatalysts are gaining more attention nowadays and have the potential to outperform chemical catalysts for biodiesel production. The development of enzymes in biodiesel synthesis is aimed to offshoot the various concerns associated with chemical catalysis. New biochemical routes to biodiesel production, based on the use of enzymes, are becoming very interesting [18] [38] [39] [40]. Several lipases from microbial strains, including Pseudomonas fluorescens, Pseudomonas cepacia, Rhizomucor miehei, Rhizopus oryzae, Candida rugosa, Thermomyces lanuginosus, and Candida antarctica, have been reported to have record success in transesterification activity. The recent studies using methyl acetate as the acyl acceptor and soybean oil illustrate that the use of this acyl acceptor does not lead to inhibition of the enzyme [41]-[47].

Commercially, the prospect of biological catalyst is becoming promising in biodiesel synthesis due in part to enhanced production processes and feasibility of use in new operational environment, thus organisms that are capable of enzyme secretion have been modified genetically for optimal secretion and for improved catalytic activities such that no less than $75 \%$ of industrial market have been fortified by hydrolytic enzymes like protease, lipase and amylase. Research enquiry into these lipases are becoming increasing, though low production have been reported in current enzyme market, a constraint attributable to the feedstock selection, operational time and purification requirement [48].

In addition to propensity of hydrolyzing triacylglycerol (TAG) to glycerol and free fatty acids, esterification, transesterification and aminolysis in non-aqueous media are some other processes that have utilized the activities of lipase. Besides, they are among the hydrolases with enormous industrial propensities and have find application in other production processes such as confectioneries, detergent, chemical and pharmaceutical industries [48].

Lipases possess tremendous potential for application in biotechnology because they are capable of acting at the aqueous and non-aqueous interface which differentiates them from other enzymes. Purification to homogeneity may not be necessary be required but a partial purification to a certain degree is recommended for use in industries [48]. Despite the tremendous advantage of enzymatic alcoholysis, this approach however has some shortcomings which include loss of enzyme activity due to deleterious alcohol effects, water deactivation and glycerol inhibition [18] [49]. Moreover, the high cost of enzyme production still remain the major impediment to commercialization of enzyme-catalyzed processes.

\subsection{Non-Catalyzed Process}

Supercritical alcohol transesterification is process of biodiesel production designed to offshoot the many issues such as huge volume of wastewater effluent and feedstock selectivity [50] associated with conventional transesterification with chemical catalyst. Nevertheless, supercritical alcohol method is faced with 
high temperatures requirement $\left(350^{\circ} \mathrm{C}-400^{\circ} \mathrm{C}\right)$ and pressures $(10-25 \mathrm{MPa})$ and therefore the high capital cost.

In an effort to lessen the effect of these drawbacks, a catalyst-free technique for the transesterification of vegetable oils using an alcohol under supercritical conditions has been suggested, subject to the advantages of fuel quality and environmental considerations [51] [52] [53]. Based on the available reports in literature, this method of catalyst-free alcoholysis reactions at high temperature and pressure conditions enable robust phase solubility and decreased mass-transfer restrictions. The reaction rate is incredibly increased in the supercritical state thereby ensuring reaction completion in shorter period while a less difficult separation and purification steps is ensured [51].

Moreover, the absence of a catalyst is augmented by the presence of the alcohol which serves a dual purpose of reactant as well functions as a catalyst [54]. Besides, supercritical method (SCM) has been reported to be more tolerant with the associated water and free fatty acids in the feedstock compared to the usual alkali-catalyzed procedure. Therefore, the technique is much more effective to various types of vegetable oils, this has raised unprecedentedly the interest in research involving the use of this approach.

The economic analysis of biodiesel synthesis by homogeneous alkaline catalysis and SCM routes had been investigated previously [55] [56]. The energy utilization was observed to be similar in the two approaches. Higher energy requirement in the SCM due to the heating involve, is the cause for the higher costs, however, this cost is compensated for by the less downstream operation requirement for the product, which alternatively is the reason for higher cost in the usual homogenous catalytic production approach.

Marchetti and Errazu [57] weighted different methods for biodiesel production with low-valued oil resource that are predominantly rich in free fatty acids. They submitted that the SCM is an attractive alternative from technological perspective. Besides, economic consideration informs low wastewater generation and a food grade glycerin production as a byproduct. Thus, SCM approach is an important and promising procedure in biodiesel production.

Available research works in literature highlight some measures that can apparently lower the exorbitant operating costs and product degradation. These suggested measures include the use of co-solvent, hydro-esterification approach, utilization of heterogeneous catalyst especially from renewable sources, a twostep method of triglycerides hydrolysis in subcritical water followed by esterification of the hydrolysates and employing different reactor configurations with increased mass transfer operating in continuous mode (micro-reactor or packed bed reactor).

\subsection{Biomass-Based Heterogeneous Catalysts, Modification and Performance}

Predominantly, development of heterogeneous catalysts from renewable source 
received attention due to the basic nature of the carbonaceous constituents within these materials. Various studies available in literature (Table 2) sourced for materials such as seafood shells, animal bones and industrial wastes materials. These renewable heterogeneous catalyst are explored to overcome limitations of the SCM which majorly is the capital cost due to high temperature and pressure requirement. The materials are cheap and can be easily recovered and reused. Besides, no neutralization of the wastewater generated in the conventional process is required and it can be operated at similar reaction conditions as that of the conventional alkaline transesterification. Thus, the cheap nature and sustainable benefit of these materials make this method a promising and viable method. Researchers have explored these approach for sustainable biodiesel development.

Among the various works available in literature is the work of Viriya-empikul et al. [58]. They utilized resources such as waste egg shell, golden apple snail shell and Meretrix venus derived from industrial waste. These materials were

Table 2. Renewable heterogeneous catalyst.

\begin{tabular}{|c|c|c|c|c|c|c|}
\hline Catalyst source & Modification & Modification condition & Feedstocks & FAME conversion & Catalyst dose & Reference \\
\hline Oyster shell & Combustion & $700^{\circ} \mathrm{C}$ & Soybean oil & $>70 \%(\mathrm{Y}), 5 \mathrm{~h}$ & 25 wt. $\%$ & {$[64]$} \\
\hline Waste eggshell & Calcination & $200^{\circ} \mathrm{C}-1000^{\circ} \mathrm{C}, 2 \mathrm{~h}$ & Soybean oil & $95 \%(\mathrm{Y}), 3 \mathrm{~h}$ & 3 wt. $\%$ & {$[65]$} \\
\hline Shell of Turbonillastriatula & Calcination & $800^{\circ} \mathrm{C}, 4 \mathrm{~h}$. & Mustard oil & $93.3 \%(Y), 6 \mathrm{~h}$ & 3 wt.\% & [60] \\
\hline Waste fish scale (Labeorohita) & Calcination & $>997.42^{\circ} \mathrm{C}, 2 \mathrm{~h}$ & Soybean oil & $97.73 \%(\mathrm{Y})$ & 1.01 wt. $\%$ & {$[66]$} \\
\hline eggshell & $\begin{array}{l}\text { Calcination- } \\
\text { hydration- } \\
\text { dehydration }\end{array}$ & $\begin{array}{c}900^{\circ} \mathrm{C}, 2.5 \mathrm{~h}, \\
60^{\circ} \mathrm{C}, 6 \mathrm{~h} \\
600^{\circ} \mathrm{C}, 3 \mathrm{~h}\end{array}$ & Waste frying oil & $94.52 \%(\mathrm{C})$ & 5 wt. $\%$ & [67] \\
\hline $\begin{array}{c}\text { Industrial waste. (Eggshell, } \\
\text { golden apple snail shell, } \\
\text { Meretrixvenus) }\end{array}$ & Calcination & $800^{\circ} \mathrm{C}, 2-4 \mathrm{~h}$ & Palm olein oil & $>90 \%(\mathrm{C}), 2 \mathrm{~h}$ & 10 wt. $\%$ & {$[58]$} \\
\hline Animal bone & calcination & $800^{\circ} \mathrm{C}$ & palm oil & $96.78 \%(\mathrm{C}), 4 \mathrm{~h}$ & 20 wt. $\%$ & [59] \\
\hline Industrial eggshell & Calcination & $800^{\circ} \mathrm{C}, 4 \mathrm{~h}$. & Palm oil & $96.7 \%(C) 4 \mathrm{~min}$ & 15 wt. $\%$ & {$[61]$} \\
\hline $\begin{array}{c}\text { Clamshell } \\
\text { (Mereterixmereterix) }\end{array}$ & Calcination & $900^{\circ} \mathrm{C}, 3.5 \mathrm{~h}$ & Waste frying oil & $97 \%,(C) 3 \mathrm{~h}$ & $3.0 \mathrm{~g}$ & {$[62]$} \\
\hline Waste mussel shell & Calcination & $1050^{\circ} \mathrm{C}$ & Soybean oil & $100(\mathrm{C}), 94.1 \%(\mathrm{Y})$ & 12 wt. $\%$ & {$[68]$} \\
\hline $\begin{array}{l}\text { Waste shell of mussel, cockle, } \\
\text { scallop }\end{array}$ & Calcination & $1000^{\circ} \mathrm{C}, 4 \mathrm{~h}$ & Palm oil & $95 \%(C), 3 \mathrm{~h}$ & 10 wt. $\%$ & [69] \\
\hline Chicken bones & Calcination & $900^{\circ} \mathrm{C}$ & $\begin{array}{l}\text { Waste cooking } \\
\text { oil }\end{array}$ & $89.33 \%(\mathrm{C})$ & $5.0 \mathrm{~g}$ & [63] \\
\hline $\begin{array}{l}\text { Angel wing shell } \\
\text { (cyrtopleuracostata) }\end{array}$ & Calcination & $800^{\circ} \mathrm{C}, 900^{\circ} \mathrm{C}, 2 \mathrm{~h}$ & Microalgae oil & $84.11 \%(\mathrm{Y})$ & 9.0 wt. $\%$ & {$[70]$} \\
\hline palm kernel shell & $\begin{array}{l}\text { Gasification and } \\
\text { Calcination }\end{array}$ & $800^{\circ} \mathrm{C}, 2 \mathrm{~h}$ & Sunflower oil & $99.0 \%(C)$ & 5.0 wt. $\%$ & {$[71]$} \\
\hline $\begin{array}{l}\text { Animal bone modified on } \\
\qquad \mathrm{KOH}\end{array}$ & Calcination & $900^{\circ} \mathrm{C}$ & Jatropha oil & $96.1 \%$ & 6.0 wt. $\%$ & {$[72]$} \\
\hline Musabalbisianacolla peel & $\begin{array}{l}\text { Air burning and } \\
\text { calcination }\end{array}$ & $700^{\circ} \mathrm{C}, 4 \mathrm{~h}$ & $\begin{array}{l}\text { Waste cooking } \\
\text { oil }\end{array}$ & $100 \%(\mathrm{C})$ & 2 wt.\% & {$[73]$} \\
\hline $\begin{array}{l}\text { Waste ostrich and chicken } \\
\text { eggshell }\end{array}$ & calcination & $1000^{\circ} \mathrm{C}, 4 \mathrm{~h}$ & $\begin{array}{l}\text { Waste cooking } \\
\text { oil }\end{array}$ & $94 \%, 96 \%(C)$ & 1.5 wt. $\%$ & {$[74]$} \\
\hline River snail shell & calcination & $600^{\circ} \mathrm{C}-1000^{\circ} \mathrm{C}, 3 \mathrm{~h}$ & Palm oil & $98.5 \%$ & 5.0 wt. $\%$ & {$[75]$} \\
\hline
\end{tabular}


calcined in air at $800^{\circ} \mathrm{C}$ for $2.4 \mathrm{~h}$ optimal conditions. They employed the synthesized catalyst in transesterification of palm olein oils. A comparative performance was observed as that obtainable with alkaline catalyst and recorded high catalytic activity in term of FAME conversion well above $90 \%$ in $2 \mathrm{~h}$. Obadiah et al. [59] employed waste animal bones as cheap resource for biodiesel production from palm oil esterification. The catalyst was calcined to transform the calcium phosphate in the bone to hydroxyapatite at $800^{\circ} \mathrm{C}$ temperature. $20 \mathrm{wt} . \%$ of the catalyst produced incredible result at mild reaction condition to achieve $96.78 \%$ conversion of methyl esters. The catalyst was observed to be comparable in performance with that observed with laboratory grade $\mathrm{CaO}$.

Biodiesel production utilizing waste shell of Turbonilla striatula as solid oxide was investigated by Boro et al. [60]. The shell was calcined at ranges of temperature for $4 \mathrm{~h}$ and was used in transesterification of mustard oil. Optimum calcination temperature of $800^{\circ} \mathrm{C}$ was determined and the calcined catalyst exhibit enhanced surface area and higher pore volume. $3 \mathrm{wt} . \%$ of the catalyst yielded 93.3\% biodiesel at mild reaction conditions in about $6 \mathrm{~h}$. The catalyst could as well be reused only about two cycles as pronounced catalytic activity was lost after the second cycle. Catalytic efficiency of waste industrial eggshell as heterogeneous catalyst in microwave-assisted transesterification of palm oil was studied by khemthong et al. [61]. The waste eggshell was calcined in air at $800^{\circ} \mathrm{C}$ for $4 \mathrm{~h}$. The calcined catalyst exhibit high $\mathrm{CaO}$ content of about $99.2 \%$ and was observed to be efficient in transesterification of palm oil producing 96.7\% FAME conversion with $15 \mathrm{wt} . \%$ of catalyst. The catalyst also showed high reusability potential.

Nair et al. [62] synthesized heterogeneous catalyst from clamshell (Mereterix mereterix) which was calcined at $900^{\circ} \mathrm{C}$ for $3.5 \mathrm{~h}$. This catalyst was employed in transesterification of waste frying oil at $60^{\circ} \mathrm{C}$ for $3 \mathrm{~h}$. A biodiesel yield and conversion of about $89 \%$ and $97 \%$ respectively was obtained optimally with $3.0 \mathrm{~g}$ of the catalyst. Besides, chicken bones derived heterogeneous catalyst was employed in the transesterification of waste cooking oil in biodiesel production by Farooq et al. [63]. This catalyst was calcined at $900^{\circ} \mathrm{C}$ and was observed to exhibit good catalytic activity. Utilization of the catalyst generated $89.33 \%$ yield of the product with $5.0 \mathrm{~g}$ of the catalyst under mild reaction conditions within short reaction time of $4 \mathrm{~h}$.

Nakatani et al. [64] produced biodiesel from soy bean oil using combusted oyster shell waste as heterogeneous catalyst. Calcination temperature was $700^{\circ} \mathrm{C}$ and optimum biodiesel was achieved using $25 \mathrm{wt} . \%$ the catalyst at $5 \mathrm{~h}$ reaction time to produce high purity soybean methyl esters of yield above $70 \%$. Wei et al. [65] applied calcined waste eggshell as cheap heterogeneous catalyst in transesterification of soybean oil. The calcination of the eggshell was done between $200^{\circ} \mathrm{C}-1000^{\circ} \mathrm{C}$ temperature ranges for $2 \mathrm{~h}$. the study resulted in more than $95 \%$ yield of soybean biodiesel in $3 \mathrm{~h}$ using $3 \mathrm{wt}$.\% of the catalyst. Reusability test showed that the catalyst could be reused up to 13 times with no apparent diminished catalytic activity. 
Application of waste fish scale calcined above $900^{\circ} \mathrm{C}$ for $2 \mathrm{~h}$ was investigated by Chakraborty et al. [66]. The calcined fish scale was utilized as heterogeneous catalyst, the dose was $1.01 \mathrm{wt} . \%$ relative to oil and feasibility of the catalyst was possible for up to 6 times reaction cycles. Moreover, Niju et al. [67] utilized modified eggshell in transesterification of waste frying oil. To obtain high quality methyl ester, the modification was calcination-hydration-dehydration approach to transform the material to an oxide with high catalytic efficiency. The application of the catalyst in biodiesel synthesis from waste frying oil ensure $94.52 \%$ conversion of the oil with $5 \mathrm{wt} . \%$ of the modified catalyst in $1 \mathrm{~h}$ reaction time. Reusability of the catalyst inform probable use of up to 6 cycles with yield above $90 \%$.

Rezaei et al. [68] optimized biodiesel production from soybean oil utilizing calcined waste mussel shell as an eco-friendly, cheap catalyst. The calcination to convert calcium carbonate to $\mathrm{CaO}$ was due at temperature of $1050^{\circ} \mathrm{C}$ optimum. The soybean methyl ester was produced with $12 \mathrm{wt} . \%$ of the calcined catalyst to generate $100 \%$ pure product and $94.1 \%$ yield. The reusability test of the catalyst ensure 5 times reaction cycles. Moreover, Buasri et al. [69] employed the activity of calcium oxide derived from waste shell of mussel, cockle and scallop as heterogeneous catalyst for transesterification of palm oil with methanol. The catalyst was prepared by calcination at $100^{\circ} \mathrm{C}$ for $4 \mathrm{~h}$. After $3 \mathrm{~h}$ reaction time, up to $95 \%$ conversion of the feedstock was achieved with $10 \mathrm{wt} . \%$ of the catalyst. The catalyst exhibit good activity and reusability up to 4 times reaction cycles.

Cyrtopleura costata (Angel wing shell) was utilized as heterogeneous catalyst in the conversion of microalgae oil for biodiesel synthesis by Osman et al. [70]. The catalyst (AWS) was modified through calcination at $800^{\circ} \mathrm{C}$ and $900^{\circ} \mathrm{C}$ over 2 $\mathrm{h}$ period to convert $\mathrm{CaCO}_{3}$ to activate metal oxide phase. The study was discovered to offer higher basicity and surface area and was employed in the conversion of the feedstock. Optimized conditions of 1:150 and 9 wt.\% for oil to methanol molar ratio and catalyst loading respectively produced a FAME yield of $84.11 \%$ in $1 \mathrm{~h}$ reaction time. The study also recorded a 3 times reusability of the catalyst.

In another study, Bazargan et al. [71] employed palm kernel shell for transesterification of sunflower oil. The palm kernel shell haven been subjected to thermal treatment in a gasifier to produce a calcium oxide based biochar was calcined at $800^{\circ} \mathrm{C}$ for $2 \mathrm{~h}$, it was then utilized for catalytic conversion of feedstock to biodiesel utilizing 9:1 molar ratio of methanol to oil at $60^{\circ} \mathrm{C}$ reaction temperature. The study recorded $99 \%$ conversion of the feedstock after $5 \mathrm{~h}$ reaction time. Moreover, Nisan et al. [72] applied calcined animal bone modified with potassium hydroxide as heterogeneous solid base catalyst for transesterification of high free fatty acid Jatropha. The study recorded high catalytic activity for transesterification of the feedstock. Optimum reaction condition of 9:1 methanol to oil molar ratio, catalyst dose of $6.0 \mathrm{wt} . \%$, reaction temperature of about $70^{\circ} \mathrm{C}$ at $3 \mathrm{~h}$ reaction time produced $96.1 \%$ FAME yield. The catalyst was reusable 
up to four cycle without pronounce deactivation.

Recently, Gohain et al. [73] utilized Musa balbisiana colla peel to produce an eco-friendly and highly effective heterogeneous base catalyst for biodiesel production through green practices. In the work, waste cooking oil was used as the feedstock to synthesize the biodiesel. An incredible 100\% conversion was achieved by the catalyst which was modified after being washed and dried by burning in air and subsequent calcination of the formed ash at $700^{\circ} \mathrm{C}$ for $4 \mathrm{~h}$ in a muffle furnace to obtain the calcined catalyst. $2 \mathrm{wt} . \%$ of the catalyst, $6: 1$ methanol to oil molar ratio, $60^{\circ} \mathrm{C}$ reaction temperature and $3 \mathrm{~h}$ reaction time were found to be optimized conditions for conversion. Significant reduction in the biodiesel conversion was observed after each successive reuse of the catalyst which was attributed to leaching and loss of catalyst.

Waste ostrich and chicken eggshells as heterogeneous base catalysts were investigated by Tan et al. [74] for biodiesel production from waste cooking oil. The eggshell samples utilized in the study were manually crushed and sieved to obtain a particle size lesser than $0.5 \mathrm{~mm}$. The fine powder was subsequently calcined in a muffle furnace at $1000^{\circ} \mathrm{C}$ for $4 \mathrm{~h}$. The prepared catalyst was then comparatively applied for conversion of the feedstock in a two-step transesterification reaction. The catalyst prepared from ostrich eggshell was discovered to produce higher FAME yield (96\%) compared to the chicken eggshell (94\%). This was attributed to larger surface area, improved basicity and smaller particle size of the ostrich-eggshell compared to chicken-eggshell. Optimum reaction condition recorded 12:1 methanol to oil molar ratio, $2 \mathrm{~h}$ reaction time, $65^{\circ} \mathrm{C}$, reaction temperature and agitation of $250 \mathrm{rpm}$.

River snail shell was employed for transesterification of Palm oil in a study conducted by Roschat et al. [75]. The snail shell was calcined between $600^{\circ} \mathrm{C}$ $1000^{\circ} \mathrm{C}$ for $3 \mathrm{~h}$. The reaction was aided with a co-solvent and the catalytic performance of the prepared catalyst as well as the reaction kinetic was investigated. Optimum reaction conditions of $5 \mathrm{wt} . \%$ of the catalyst, 12:1 molar ratio of the methanol to oil, reaction temperature of $65^{\circ} \mathrm{C}$ and reaction time of $1.5 \mathrm{~h}$ produced $98.5 \%$ yield of the fatty ester.

\section{Conclusions}

The need for a more cost effective fuel is a major prerequisite for development of biodiesel. Conventional catalysis using homogeneous basic catalyst generates enormous wastewater and is prone to purification problem. Hence, pure biodiesel from this approach cannot be ultimately guaranteed. Enzymatic approach is otherwise very expensive in practice. Heterogeneous catalyst derived from organic sources ensures sustainable development and due to its basic nature, produce great result in conversion of triglycerides. An array of the cheap biomassderived catalysts as presented have been investigated, nevertheless, there are other organic materials that need be researched. Calcination temperature and time are observed to be contributory to the performance of the catalyst. Besides, 
catalyst modification is majorly restricted to calcination as heat pretreatment requiring enormous energy, effort need be put in place to offshoot this process to ascertain a more sustainable biodiesel.

Among the various heterogeneous catalysts explored, seafood shell materials were observed to perform better at lower reaction time compared to other resource such as animal bone and industrial waste shells, however, majority of other resources were reported to generate yield and conversion well above $90 \%$, hence the prospect of heterogeneous catalysis in biodiesel development promise to be an economically viable approach. Beside the fact that these biomass-derived resources are relatively less abundant in nature for commercialization prospect, the high energy requirement for modification of the catalyst to enhance it activity, rapid reduction of catalyst efficiency due to contact of basic sites with ambient $\mathrm{CO}_{2}$ and water as well as possible active site decrease caused by reaction with FFA and leaching of $\mathrm{CaO}$ into polar solvent which calls for further research into these resource, the utilization of these biomas-based materials promise to be renewable and sustainable.

\section{References}

[1] Demirbas, A. (2008) Biodiesel: A Realistic Fuel Alternative for Diesel Engine. Springer.

[2] Demirbas, A. (2003) Biodiesel Fuels from Vegetable Oils via Catalytic and NonCatalytic Supercritical Alcohol Transesterifications and Other Methods: A Survey. Energy Conversion and Management, 44, 2093-2109. https://doi.org/10.1016/S0196-8904(02)00234-0

[3] Canakci, M. and Van Gerpen, J. (2001) Biodiesel Production from Oils and Fats with High Free Fatty Acids. Transactions of the American Society of Agricultural Engineers, 44, 1429-1436. https://doi.org/10.13031/2013.7010

[4] Turner, T.L. (2005) Modelling and Simulation of Reaction Kinetics for Biodiesel Production. Master's Thesis, Mechanical Department North Carolina State University, USA.

[5] Vasudevan, P.T. and Briggs, M. (2008) Biodiesel Production-Current State of the Art and Challenges. Journal of Industrial Microbiology and Biotechnology, 35, 421 430. https://doi.org/10.1007/s10295-008-0312-2

[6] Gutiérrez, L.F., Óscar, J., Sánchez, O.J., Carlos, A. and Cardona, C.A. (2009). Process Integration Possibilities for Biodiesel Production from Palm Oil Using Ethanol Obtained from Lignocellulosic Residues of Oil Palm Industry. Bioresource Technology, 100, 1227-1237. https://doi.org/10.1016/j.biortech.2008.09.001

[7] Ghaly, A.E., Dave, D., Brooks, M.S. and Budge, S. (2010) Production of Biodiesel by Enzymatic Transesterification: Review. American Journal of Biotechnology and Biotechnology, 6, 54-76. https://doi.org/10.3844/ajbbsp.2010.54.76

[8] Pearl, G.G. (2002) Animal Fat Potential for Bioenergy Use. Bioenergy, The Biennial Bioenergy Conference, Boise, 22-26 September 2002.

[9] Aranda, D.A.G., da Silva, C.C.C. and Detoni, C. (2009) Current Processes in Brazilian Biodiesel Production. International Review of Chemical Engineering (I.RE.CH.E), 1, 603-608.

[10] Korbitz, W. (2002) New Trends in Developing Biodiesel World-Wide. Asia Bio- 
Fuels. Evaluating and Exploiting the Commercial Uses of Ethanol, Fuel Alcohol and Biodiesel, Singapore, 22-23 April 2002.

[11] Pinto, A.C., Guarieiro, L.L.N., Rezende, M.J.C., Ribeiro, N.M., Torres, E.A., Lopes, W.A., Pereira, P.A.P. and Andrade, J.B. (2005) Biodiesel: An Overview. Journal of the Brazilian Chemical Society, 16, 1313-1330. https://doi.org/10.1590/S0103-50532005000800003

[12] Shay, E.G. (1993) Diesel Fuel from Vegetable Oils: Status and Opportunities. Biomass Bioenergy, 4, 227-242. https://doi.org/10.1016/0961-9534(93)90080-N

[13] Goering, C.E., Camppion, R.N., Schwab, A.W. and Pryde, E.H. (1982) Vegetable Oil Fuels. Proceedings of the International Conference on Plant and Vegetable Oils as Fuels, Fargo, ND, August 1982, 279-286.

[14] Pryor, R.W., Hanna, M.A., Schinstock, J.L. and Bashford, L.L. (1982) Soybean Oil Fuel in a Small Diesel Engine. Transactions of the ASAE, 26, 333-338. https://doi.org/10.13031/2013.33931

[15] Schuchardt, U., Serchelia, R. and Vargas, R.M. (1998) Transesterification of Vegetable Oils: A Review, Journal of the Brazilian Chemical Society, 9, 199-210. https://doi.org/10.1590/S0103-50531998000300002

[16] Marchetti, J.M., Miguel, V.U. and Errazu, A.F. (2008) Techno-Economic Study of Different Alternatives for Biodiesel Production. Fuel Processing Technology, 89, 740-748. https://doi.org/10.1016/j.fuproc.2008.01.007

[17] Robles-Medina, A., Gonzalez-Moreno, P.A., Esteban-Cerdan, L. and Molina-Grima, E. (2009) Biocatalysis: Towards Ever Greener Biodiesel Production. Biotechnology Advances, 27, 398-408. https://doi.org/10.1016/j.biotechadv.2008.10.008

[18] Fukuda, H., Kondo, A. and Noda, H. (2001) Biodiesel Fuel Production by Transesterification of Oils. Journal of Bioscience and Bioengineering, 92, 405-416. https://doi.org/10.1016/S1389-1723(01)80288-7

[19] Bacovsky, D., Korbitz, W., Mittelbach, M. and Worgetter, M. (2007) Biodiesel Production: Technologies and European Providers. IEA Task 39 Report T39-B6.

[20] Leung, D.Y.C., Wu, X. and Leung, M.K.H. (2010) A Review on Biodiesel Production Using Catalyzed Transesterification. Applied Energy, 87, 1083-1095.

https://doi.org/10.1016/j.apenergy.2009.10.006

[21] Leung, D.Y.C. and Guo, Y. (2006) Transesterification of Neat and Used Frying Oil: Optimization for Biodiesel Production. Fuel Processing Technology, 87, 883-890. https://doi.org/10.1016/j.fuproc.2006.06.003

[22] Fjerbaek, L., Christensen, K.V. and Norddahl, B. (2009) A Review of the Current State of Biodiesel Production Using Enzymatic Transesterification. Biotechnology and Bioengineering, 102, 1298-1315. https://doi.org/10.1002/bit.22256

[23] Sarin, A. (2012) Biodiesel Production and Properties. Royal Society of Chemistry, Cambridge.

[24] Encinar, J.M., Gonzalez, J.F. and Rodrguez-Reinares, A. (2005) Biodiesel from Used Frying Oil. Variables Affecting the Yields and Characteristics of the Biodiesel. Industrial and Engineering Chemistry Research, 44, 5491-5499. https://doi.org/10.1021/ie040214f

[25] Li, L., Du, W. and Liu, D. (2006) Lipase-Catalyzed Transesterification of Rapeseed Oil for Biodiesel Production with a Novel Organic Solvent as the Reaction Medium. Journal of Molecular Catalysis B: Enzymatic, 43, 58-62. https://doi.org/10.1016/j.molcatb.2006.06.012

[26] Rashid, U., Anwar, F., Moser, R.B. and Knotte, G. (2008) Moringa oleifera: A Possi- 
ble Source of Biodiesel. Bioresource Technology, 99, 8175-8179.

https://doi.org/10.1016/j.biortech.2008.03.066

[27] Encinar, J.M., Gonzalez, J.F. and Rodriguez-Reinares, A. (2007) Ethanolysis of Used Frying Oil. Biodiesel Preparation and Characterization. Fuel Processing Technolo$g y$, 88, 513-522. https://doi.org/10.1016/j.fuproc.2007.01.002

[28] Rashid, U., Anwar, F. and Knotte, G. (2009) Evaluation of Biodiesel Obtained from Cotton Seed Oil. Fuel Processing Technology, 90, 1157-1163. https://doi.org/10.1016/j.fuproc.2009.05.016

[29] Casas, A., Fernández, C.M., Ramos, M.J., Pérez, A. and Rodríguez, J.F. (2010) Optimization of the Reaction Parameters for Fast Pseudo Single-Phase Transesterification of Sunflower Oil. Fuel, 89, 650-658. https://doi.org/10.1016/j.fuel.2009.08.004

[30] Helwani, Z., Othman, M.R., Aziz, N., Kim, J. and Fernando, W.J.N. (2009) Solid Heterogeneous Catalysts for Transesterification of Triglycerides with Methanol: A Review. Applied Catalysis A: General, 363, 1-10. https://doi.org/10.1016/j.apcata.2009.05.021

[31] Abbaszaadeh, A., Ghobadian, B., Omidkhah, M.R. and Najafi, G. (2012) Current Biodiesel Production Technologies: A Comparative Review. Energy Conversion and Management, 63, 138-148. https://doi.org/10.1016/j.enconman.2012.02.027

[32] Kiss, F.E., Jovanović, M. and Bošković, G.C. (2010) Economic and Ecological Aspects of Biodiesel Production over Homogeneous and Heterogeneous Catalysts. Fuel Processing Technology, 91, 1316-1320. https://doi.org/10.1016/j.fuproc.2010.05.001

[33] Veljkovic, V.B., Stamenkovic, O.S., Todorovic, Z.B., Lazic, M.L. and Skala, D.U. (2009) Kinetics of Sunflower Oil Methanolysis Catalyzed by Calcium Oxide. Fuel, 88, 1554-1562. https://doi.org/10.1016/j.fuel.2009.02.013

[34] Alonso, D.M., Mariscal, R., Moreno-Tost, R., Poves, M.D. and Granados, M. (2007) Potassium Leaching during Triglycerides Transesterification Using $\mathrm{Ak} / \mathrm{Y}-\mathrm{Al}_{2} \mathrm{O}_{3}$ Catalysis Communications, 8, 2074-2080. https://doi.org/10.1016/j.catcom.2007.04.003

[35] Liu, X., He, H., Wang, Y. and Zhu, S. (2007) Transesterification of Soybean Oil to Biodiesel Using SrO as a Solid Base Catalyst. Catalysis Communications, 8, $1107-$ 1111. https://doi.org/10.1016/j.catcom.2006.10.026

[36] Umdu, E.S., Tuncer, M. and Seker, E. (2009) Transesterification of Nannochloropsis oculata microalga's Lipid to Biodiesel on $\mathrm{Al}_{2} \mathrm{O}_{3}$ Support $\mathrm{CaO}$ and $\mathrm{MgO}$ Catalysts. Bioresource Technology, 100, 2828-2831. https://doi.org/10.1016/j.biortech.2008.12.027

[37] Xie, W., Huang, X. and Li, H. (2007) Soybean Oil Methyl Esters Preparation Using $\mathrm{NaX}$ Zeolites Loaded with $\mathrm{KOH}$ as a Heterogeneous Catalyst. Fuel, 89, 2939-2944. https://doi.org/10.1016/j.biortech.2006.04.003

[38] De Oliveira, D., Di Luccio, M., Faccio, C., Dalla Rosa, C., Bender, J.P., Lipke, N., Menoncin, S., Amroginski, C. and De Oliveira, J.V. (2004) Optimization of Enzymatic Production of Biodiesel from Castor Oil in Organic Solvent Medium. Applied Biochemistry and Biotechnology, 115, 771-780. https://doi.org/10.1385/ABAB:115:1-3:0771

[39] Chang, H.M., Liao, H.F., Lee, C.C. and Shieh, C.J. (2005) Optimized Synthesis of Lipase-Catalyzed Biodiesel by Novozym 435. Journal of Chemical Technology \& Biotechnology, 80, 307-312. https://doi.org/10.1002/jctb.1166

[40] Noureddini, H., Gao, V. and Philkana, R.S. (2005) Immobilized Pseudomonas ce- 
pacia Lipase for Biodiesel Fuel Production from Soybean Oil. Bioresource Technology, 96, 769-777. https://doi.org/10.1016/j.biortech.2004.05.029

[41] Deng, L., Xu, X., Haraldsson, G.G., Tan, T.W. and Wang, F. (2005) Enzymatic Production of Alkyl Esters through Alcoholysis: A Critical Evaluation of Lipases and Alcohols. Journal of the American Oil Chemists Society, 82, 341-347. https://doi.org/10.1007/s11746-005-1076-3

[42] Soumanou, M.M. and Bornscheuer, U.T. (2003) Improvement in Lipase-Catalyzed Synthesis of Fatty Acid Methyl Esters from Sunflower Oil. Enzyme and Microbial Technology, 33, 97-103. https://doi.org/10.1016/S0141-0229(03)00090-5

[43] Matsumoto, T., Takahashi, S., Kaieda, M., Ueda, M. and Tanaka, A. (2001) Yeast Whole-Cell Biocatalyst Constructed by Intracellular Overproduction of Rhizopus oryzae Lipase Is Applicable to Biodiesel Fuel Production. Applied Microbiology and Biotechnology, 57, 515-520. https://doi.org/10.1007/s002530100733

[44] Chen, J.W. and Wu, W.T. (2003) Regeneration of Immobilized Candida Antarctica lipase for Transesterification. Journal of Bioscience and Bioengineering, 95, 466-469. https://doi.org/10.1016/S1389-1723(03)80046-4

[45] Cavalcanti-Oliveira, E., da Silva, P.R., Ramos, A.P., Aranda, D.A.G. and Freire, D.M.G. (2010) Study of Soybean Oil Hydrolysis Catalyzed by Thermomyces lanuginosus Lipase and Its Application to Biodiesel Production via Hydroesterification. Enzyme Research, 2011, Article ID: 618692.

[46] Lai, C.C., Zullaikah, S., Vali, S.R. and Ju, Y.H. (2005) Lipase-Catalyzed Production of Biodiesel from Rice Bran Oil. Journal of Chemical Technology and Biotechnology, 80, 331-337. https://doi.org/10.1002/jctb.1208

[47] Du, W., Xu, Y., Liu, D. and Zeng, J. (2004) Comparative Study on Lipase-Catalyzed Transformation of Soybean Oil for Biodiesel Production with Different Acyl Acceptors. Journal of Molecular Catalysis B: Enzymatic, 30, 125-129. https://doi.org/10.1016/j.molcatb.2004.04.004

[48] Basheer, S.A and Thenmozhi, M. (2010) Reverse Micellar Separation of Lipases: A Critical Review. International Journal of Chemical Sciences, 8, S57-S67.

[49] Ranganathan, S.V., Narasimhan, S.L. and Muthukumar, K. (2008) An Overview of Enzymatic Production of Biodiesel. Bioresource Technology, 99, 3975-3981. https://doi.org/10.1016/j.biortech.2007.04.060

[50] Meher, L.C., Sagar, D.V. and Naik, S.N. (2006) Technical Aspects of Biodiesel Production by Transesterification-A Review. Renewable and Sustainable Energy Reviews, 10, 248-268. https://doi.org/10.1016/j.rser.2004.09.002

[51] Kusdiana, D. and Saka, S. (2001) Kinetics of Transesterification in Rapeseed Oil to Biodiesel Fuels as Treated in Supercritical Methanol. Fuel, 80, 693-698.

https://doi.org/10.1016/S0016-2361(00)00140-X

[52] Demirbas, A. (2002) Biodiesel from Vegetable Oils via Transesterification in Supercritical Methanol. Energy Conversion and Management, 43, 2349-2356. https://doi.org/10.1016/S0196-8904(01)00170-4

[53] Warabi, Y., Kusdiana, D. and Saka, S. (2004) Reactivity of Triglycerides and Fatty Acids of Rapeseed Oil in Supercritical Alcohols. Bioresource Technology, 91, 283-287. https://doi.org/10.1016/S0960-8524(03)00202-5

[54] Kusdiana, D. and Saka, S. (2004) Effects of Water on Biodiesel Fuel Production by Supercritical Methanol Treatment. Bioresource Technology, 91, 289-295. https://doi.org/10.1016/S0960-8524(03)00201-3

[55] Glisic, S. and Skala, D. (2009) The Problems in Design and Detailed Analyses of 
Energy Consumption for Biodiesel Synthesis at Supercritical Conditions. The Journal of Supercritical Fluids, 49, 293-301. https://doi.org/10.1016/j.supflu.2008.12.011

[56] Deshpande, D.P., Urunkar, Y.D. and Thakare, P.D. (2012) Production of Biodiesel from Castor Oil Using Acid and Base Catalysts. Journal of Chemical Research, 2, 51-56.

[57] Marchetti, J.M. and Errazu, A.F. (2008) Comparison of Different Heterogeneous Catalysts and Different Alcohols for the Esterification Reaction of Oleic Acid. Fuel, 87, 3477-3480. https://doi.org/10.1016/j.fuel.2008.05.011

[58] Viriya-empikul, N., Krasae, P., Nualpaeng, W., Yoosuk, B. and Faungnawakij, K. (2012) Biodiesel Production over Ca-Based Solid Catalysts Derived from Industrial Wastes. Fuel, 92, 239-244. https://doi.org/10.1016/j.fuel.2011.07.013

[59] Obadiah, A., Swaroopa, G.A., Kumar, S.V., Jeganathan, K.R. and Ramasubbu, A. (2012) Biodiesel Production from Palm Oil Using Calcined Waste Animal Bone as Catalyst. Bioresource Technology, 116, 512-516. https://doi.org/10.1016/j.biortech.2012.03.112

[60] Boro, J., Ashim J. and Thakur, D.D. (2011) Solid Oxide Derived from Waste Shells of Turbonilla striatula as a Renewable Catalyst for Biodiesel Production. Fuel Processing Technology, 92, 2061-2067. https://doi.org/10.1016/j.fuproc.2011.06.008

[61] Khemthong, P., Luadthong, C., Nualpaeng, W., Changsuwan, P., Tongprem, P., Viriya-Empikul, N. and Faungnawakij, K. (2012) Industrial Eggshell Wastes as the Heterogeneous Catalysts for Microwave-Assisted Biodiesel Production. Catalysis Today, 190, 112-116. https://doi.org/10.1016/j.cattod.2011.12.024

[62] Nair, P., Singh, B., S.N., Upadhyay, S.N. and Sharma, Y.C. (2012) Synthesis of Biodiesel from Low FFA Waste Frying Oil Using Calcium Oxide Derived from Mereterix mereterix as a Heterogeneous Catalyst. Journal of Cleaner Production, 29-30, 82-90. https://doi.org/10.1016/j.jclepro.2012.01.039

[63] Farooq, M., Ramli, A. and Naeem. A. (2015) Biodiesel Production from Low FFA Waste Cooking Oil Using Heterogeneous Catalyst Derived from Chicken Bones. Renewable Energy, 76, 362-368. https://doi.org/10.1016/j.renene.2014.11.042

[64] Nakatani, N., Takamori, H., Takeda, K. and Sakugawa, H. (2009) Transesterification of Soybean Oil Using Combusted Oyster Shell Waste as a Catalyst. Bioresource Technology, 100, 1510-1513. https://doi.org/10.1016/j.biortech.2008.09.007

[65] Wei, Z. Xu, C. and Li, B. (2009) Application of Waste Eggshell as Low-Cost Solid Catalyst for Biodiesel Production. Bioresource Technology, 100, 2883-2885. https://doi.org/10.1016/j.biortech.2008.12.039

[66] Chakraborty, R., Bepari, S. and Banerjee, A. (2011) Application of Calcined Waste Fish (Labeo rohita) Scale as Low-Cost Heterogeneous Catalyst for Biodiesel Synthesis. Bioresource Technology, 102, 3610-3618. https://doi.org/10.1016/j.biortech.2010.10.123

[67] Niju, S., Meera, K.M., Begum, S. and Anantharaman, N. (2014) Modification of Egg Shell and Its Application in Biodiesel Production. Journal of Saudi Chemical Society, 18, 702-706. https://doi.org/10.1016/j.jscs.2014.02.010

[68] Rezaei, R., Mohadesi, M. andMoradi, G.R., (2013) Optimization of Biodiesel Production Using Waste Mussel Shell Catalyst. Fuel, 109, 534-541.

https://doi.org/10.1016/j.fuel.2013.03.004

[69] Buasri, A., Chaiyut, N., Loryuenyong, V., Worawanitchaphong, P. and Trongyong, S. (2013) Calcium Oxide Derived from Waste Shells of Mussel, Cockle, and Scallop as the Heterogeneous Catalyst for Biodiesel Production. The Scientific World Journal, 2013, 1-7. https://doi.org/10.1155/2013/460923 
[70] Syazwani, O.N., Rashid, U. and Taufiq-Yap, Y.H. (2015) Low-Cost Solid Catalyst Derived from Waste Cyrtopleura costata (Angel Wing Shell) for Biodiesel Production Using Microalgae Oil. Energy Conversion and Management, 101, 749-756. https://doi.org/10.1016/j.enconman.2015.05.075

[71] Bazargan, A., Kostic, M.D., Stamenkovic, O.S., Veljkovic, V.B. and McKay, G. (2015) A Calcium Oxide-Based Catalyst Derived from Palm Kernel Shell Gasification Residues for Biodiesel Production. Fuel, 150, 519-525.

https://doi.org/10.1016/j.fuel.2015.02.046

[72] Nisar, J., Razaq, R., Farooq, M., Iqbal, M., Khan, A.R., Sayed, M., Shah, A. and Rahman, I. (2017) Enhanced Biodiesel Production from Jatropha Oil Using Calcined Waste Animal Bones as Catalyst. Renewable Energy, 101,111-119.

https://doi.org/10.1016/j.renene.2016.08.048

[73] Gohain, M., Devi, A. and Deka, D. (2017) Musa balbisiana Colla Peel as Highly Effective Renewable Heterogeneous Base Catalyst for Biodiesel Production. Industrial Crops\& Products, 109, 8-18. https://doi.org/10.1016/j.indcrop.2017.08.006

[74] Tan, Y.H., Abdullah, M.O., Nolasco-Hipolito, C. and Taufiq-Yap, Y.H. (2015) Waste Ostrich- and Chicken-Eggshells as Heterogeneous Base Catalyst for Biodiesel Production from Used Cooking Oil: Catalyst Characterization and Biodiesel Yield Performance. Applied Energy, 160, 58-70. https://doi.org/10.1016/j.apenergy.2015.09.023

[75] Roschat, W., Siritanon, T., Kaewpuang, T., Yoosuk, B. and Promarak, V. (2016) Economical and Green Biodiesel Production Process Using River Snail Shells-Derived Heterogeneous Catalyst and Co-Solvent Method. Bioresource Technology, 209, 343-350. https://doi.org/10.1016/j.biortech.2016.03.038 